\title{
Keefektifan Pembelajaran POGIL dengan Strategi Konflik Kognitif untuk Mengurangi Miskonsepsi pada Materi Laju Reaksi Kelas XI SMA
}

\author{
Mafidatun Ni'mah ${ }^{1}$, Subandi ${ }^{1}$, Munzil ${ }^{1}$ \\ ${ }^{1}$ Pendidikan Kimia-Universitas Negeri Malang
}

\begin{tabular}{l}
\hline INFO ARTIKEL \\
\hline Riwayat Artikel: \\
Diterima: $31-01-2020$ \\
Disetujui: $17-09-2020$ \\
\hline
\end{tabular}

Kata kunci:

cognitive conflict; misconceptions;

reaction rate;

konflik kognitif;

miskonsepsi,

laju reaksi

\begin{abstract}
This study aims to determine what misconceptions experienced by students on the topic of reaction rates through diagnostic tests accompanied by interviews and determine the effectiveness of POGIL learning with cognitive conflict strategies in improving misconceptions. The research design used was one group pretest posttest research. The subjects in this study were 32 students of class XI one of the high schools in Sidoarjo who had obtained the reaction rate material. Student misconception data was obtained through a diagnostic test and confirmed by interview. The effectiveness of remidial learning is measured by comparing the percentage of students who experience misconceptions before and after treatment is given. The results showed that the misconceptions found at each subject were the basic concept of the reaction rate of $50 \%$, the reaction rate was $59 \%$, the reaction order was $44 \%$, the collision theory was $38 \%$, while the factors that influenced the findings were the misconceptions found on the main discussion of temperature factors by $41 \%$, a concentration factor of $25 \%$, a surface area factor of $75 \%$, and a catalyst factor by $41 \%$. POGIL learning with cognitive conflict strategies is classified as having a high level of effectiveness in reducing misconceptions.
\end{abstract}

ABSTRAK

\begin{abstract}
Abstrak: Penelitian ini bertujuan untuk mengetahui miskonsepsi apa saja yang dialami oleh siswa pada topik laju reaksi melalui tes diagnostik disertai dengan wawancara serta mengetahui efektivitas pembelajaran POGIL dengan strategi konflik kognitif dalam memperbaiki miskonsepsi. Rancangan penelitian yang digunakan adalah penelitian one grup pretest postes. Subjek dalam penelitian ini adalah 32 siswa kelas XI salah satu SMA di Sidoarjo yang telah memperoleh materi laju reaksi. Data miskonsepsi siswa didapat melalui tes diagnostik dan dikonfirmasi dengan wawancara. Keefektifan dari pembelajaran remidial diukur dengan membandingkan persentase jumlah siswa yang mengalami miskonsepsi sebelum dan sesudah diberikan perlakuan. Hasil penelitian menunjukkan bahwa miskonsepsi yang ditemukan pada masing-masing pokok bahasan laju reaksi adalah konsep dasar laju reaksi sebesar 50\%, persamaan laju reaksi 59\%, orde reaksi $44 \%$, teori tumbukan $38 \%$, sedangkan pada faktor-faktor yang memengaruhi laju reaksi ditemukan miskonsepsi pada pokok bahasan faktor suhu sebesar $41 \%$, faktor konsentrasi sebesar 25\%, faktor luas permukaan $75 \%$, dan faktor katalis sebesar $41 \%$. Pembelajaran POGIL dengan strategi konflik kognitif tergolong memiliki tingkat keefektifan yang tinggi dalam mengurangi miskonsepsi.
\end{abstract}

\section{Alamat Korespondensi:}

Mafidatun Ni'mah

Pendidikan Kimia

Universitas Negeri Malang

Jalan Semarang 5 Malang

E-mail: mafidatunnimah@gmail.com

Kimia merupakan salah satu dari cabang ilmu penting dari sains dan tujuan dari pendidikan kimia di sekolah adalah agar siswa memahami konsep dasar kimia yang berada dibalik fenomena sehari-hari (Kolomuç dan Tekin 2011). Hal ini memungkinkan bagi siswa untuk mencari jawaban dari pertanyaan apa, mengapa, dan bagaimana suatu gejala alam terjadi berkaitan dengan komposisi, struktur dan sifat, perubahan, dinamika, dan energitika zat. Meski kimia berada dalam rumpun sains, namun kimia memiliki perbedaan dengan sains lainnya. Johnstone (2000) menyatakan kimia berbeda dengan sains lain karena memiliki tiga level representasi yang tidak mudah untuk dipahami dalam waktu yang sama, yakni level makroskopis, submikroskopis, dan simbolik. Oleh sebab itu, pembelajaran kimia perlu melibatkan antara keterampilan, penalaran, dan imajinasi yang membantu siswa dalam memahami kimia secara lebih matang. 
Hal yang sering terabaikan dalam pembelajaran kimia adalah kurang atau tidak adanya pembelajaran yang menjelaskan kimia pada level submikroskopik yang bersifat abstrak. Konsep-konsep abstrak ini merupakan konsep dasar yang penting untuk dikuasai karena konsep atau teori kimia maupun sains lainnya tidak mudah dipahami jika konsep dasar tidak cukup dikuasai oleh siswa (Nakhleh 1992; Nicoll 2001) (Nakhleh 1992; Coll dan Treagust 2001; Nicoll 2001). Oleh sebab itu, sebagian besar siswa menyatakan bahwa kimia merupakan pelajaran yang sulit dikuasai sebagai akibat dari kurang mampunya siswa dalam memahami materi pada level submikroskopik (Sirhan, 2007).

Salah satu materi pada pembelajaran kimia yang dianggap sulit oleh siswa adalah laju reaksi. Pokok bahasan yang dipelajari pada materi laju reaksi, di antaranya pengertian laju reaksi, energi aktivasi, faktor yang memengaruhi laju reaksi, katalis, mekanisme reaksi (Kolomuç dan Tekin 2011). Pada materi laju reaksi ini, siswa dituntut untuk memahami ketiga level representatif yang membantu siswa dalam memahami bagaimana reaksi dapat berlangsung dan menghasilkan produk sebagai akibat dari tumbukan antar partikel serta bagaimana perubahan laju reaksinya. Hal ini dapat dilihat dari hasil penelitian terdahulu yang telah dilakukan oleh (Cakmakci, Donnelly, dan Leach 2005) yang menunjukkan bahwa siswa mengalami kesulitan memahami bagaimana laju reaksi berubah selama reaksi berlangsung, serta siswa tidak mampu memberikan penjelasan yang tepat terkait hubungan antara laju reaksi dan waktu reaksi baik secara tulis (simbolik atau grafik) maupun lisan.

Adanya kesulitan yang dialami siswa dalam memahami materi laju reaksi menyebabkan timbulnya miskonsepsi dalam diri siswa. Miskonsepsi yang terjadi pada diri siswa mungkin muncul sebelum pembelajaran diberikan (prakonsepsi) atau sebagai bentuk dari hasil pembelajaran (Wandersee, 1986) Miskonsepsi yang terjadi ini perlu diperbaiki karena konsep-konsep yang dipelajari dalam ilmu kimia saling berkaitan. Jika konsep dasar yang dimiliki siswa masih terdapat miskonsepsi, maka untuk konsep pada tingkat lanjut akan mengalami kesulitan untuk menguasainya. Begitu juga konsep laju reaksi yang berkaitan dengan konsep kesetimbangan kimia untuk materi selanjutnya. Untuk itulah konsep yang mengalami miskonsepsi sangat perlu untuk diperbaiki.

Perubahan konsep akan terjadi hanya ketika siswa dengan sadar mencoba untuk menghubungkan pengetahuan baru dengan konsep-konsep yang telah ada dalam struktur kognitifnya. Menurut (Posner dkk, 1982), jika perubahan konsep terjadi dalam pembelajaran, mula-mula siswa harus merasa tidak puas dengan gagasan yang ada. Walaupun demikian ketidakpuasan saja tidaklah cukup untuk mengubah gagasan lama menjadi gagasan baru. Harus ditumbuhkan tiga kondisi, yakni gagasan baru itu harus intelligible (dapat dimengerti), plausible (masuk akal), dan fruitful (memberi suatu kegunaan). Selain itu, Posner juga menyebutkan bahwa dalam proses pembelajaran terdapat dua proses, yaitu asimilasi dan akomodasi.

Langkah pertama yang dapat dilakukan agar proses pembelajaran untuk memperbaiki miskonsepsi dapat berjalan secara efektif adalah dengan mengidentifikasi miskonsepsi serta menggunakan pembelajaran yang efektif untuk memperbaiki miskonsepsi tersebut (Rosli dan Mohd Nasir 2017). Adapun kegiatan pembelajaran yang pernah dilakukan dan terbukti efektif dalam memperbaiki miskonsepsi diantaranya adalah pembelajaran argumen berbasis peta konsep (Santoso dan Supriadi 2015), conceptual change (Kaya dan Geban, 2012), konflik kognitif (Amarlita 2010), POGIL (Rosli dan Mohd Nasir 2017). Berdasarkan pendekatan yang dilakukan Piaget untuk menggali pengetahuan siswa, sarana yang dapat digunakan untuk memperoleh informasi terkait dengan miskonsepsi siswa dapat dilakukan dengan menggunakan wawancara secara individu (Treagust, 1988) Menurut Cetin-Dindar dan Geban (2011) wawancara dapat memberikan informasi lebih rinci tentang miskonsepsi siswa, namun dibutuhkan waktu yang lama dalam pelaksanaannya hingga didapatkan kesimpulan miskonsepsi apa saja yang dialami siswa.

Selain dengan cara wawancara, identifikasi miskonsepsi dapat pula dilakukan dengan menggunakan tes tulis. Tes tulis yang digunakan umumnya berupa tes pilihan ganda. Penggunaan tes pilihan ganda akan menyulitkan evaluator untuk menentukan apakah jawaban yang diberikan siswa benar-benar berdasarkan kemampuannya ataukah hanya tebakan bahkan memungkinkan siswa menjawab dengan asal-asalan. Adanya kelemahan pada kedua metode baik wawancara individu ataupun testulis, maka untuk mengatasi kelemahan tersebut penggunaan tes diagnostik two-tier dapat dijadikan sebagai solusi alternatif dan memudahkan bagi peneliti untuk melakukan penilaian (Tan dan Treagust 1999). Setelah miskonsepsi teridentifikasi, maka dapat dilakukan pembelajaran dengan pendekatan konstruktivis yang terbukti efektif untuk mereduksi miskonsepsi yang dialami oleh siswa (Posner dkk. 1982)

Kegiatan pembelajaran yang dilakukan diharapkan mampu mereduksi miskonsepsi. Hasil dari pembelajaran yang bermakna demikian ini akan sangat bermanfaat dan membantu siswa kedepannya ketika siswa mempelajari materi yang masih terkait. Untuk mewujudkan pembelajaran yang bermakna tersebut maka perlu dilakukan pembelajaran dengan pendekatan kontruktivis salah satunya dapat menggunakan model pembelajaran POGIL (Process-Oriented Guided Inquiry Learning) (Hanson 2006). Pembelajaran ini menekankan pada aspek perubahan, intellectual flexibility dan berpikir kritis (Sadeh dan Zion 2009). Untuk mendukung lingkungan pembelajaran tersebut, POGIL menggunakan kelompok belajar, panduan kegiatan untuk mengembangkan pemahaman, pertanyaan untuk meningkatkan berpikir kritis dan analitis, pemecahan masalah, pelaporan, metakognisi, serta tanggung jawab masing-masing tugas individu. Dalam pembelajaran POGIL, siswa dibagi menjadi kelompok belajar yang terdiri dari empat siswa yang mana masing-masing anggota kelompok memiliki peran dan tugas yang berbeda, yakni manager, presenter, recorder, strategy analyst (Hanson 2006). 
Menurut Sanjaya (Sari, Suharti, dan Srial 2015) salah satu kelemahan model pembelajaran inkuiri untuk dibelajarkan adalah model pembelajaran ini mengandalkan kesiapan berpikir siswa yang berhubungan dengan kemampuan siswa dalam menghubungkan antar konsep serta menyusun data hasil dokumentasi yang telah didapat. Selain itu, Fitriani, Irwandi, dan Murniati (2017) meyatakan bahwa pembelajaran POGIL kurang mampu untuk mengakomodasi siswa yang memiliki tingkat motivasi rendah. Kelemahan POGIL tersebutlah yang mengakibatkan retensi dalam diri siswa kurang kuat sehingga perlu dibantu dengan strategi konflik kognitif yang akan membantu siswa dalam memahami ketiga aspek representasi sekaligus. Dari tiga fase inti pembelajaran POGIL yakni eksplorasi, pembentukan konsep, dan aplikasi, strategi konflik kognitif diterapkan pada fase eksplorasi.

Pada fase eksplorasi siklus belajar, siswa diberikan model untuk memeriksa serangkaian tugas yang harus diikuti untuk mengarah ke pencapaian tujuan pembelajaran. Serangkaian pertanyaan yang diberikan dapat membimbing mereka melalui eksplorasi untuk mengembangkan pemahaman yang lebih dalam. Model yang digunakan dapat berupa hampir semua jenis informasi, seperti diagram, grafik, tabel data, satu atau lebih persamaan, metodologi, beberapa prosa, simulasi komputer, demonstrasi, atau apa pun yang merupakan kombinasi dari hal-hal tersebut. Deskripsi verbal atau sebuah penjelasan (minilectures) juga dapat digunakan sebagai model, namun tidak terlalu efektif karena tidak permanen berupa catatan yang dapat diperiksa kembali dan dianalisis oleh siswa (Hanson 2006). Proses konflik kognitif yang dialami siswa terjadi dalam tiga tahap yakni tahap pendahuluan (preliminary stage), tahap konflik (conflict stage), dan tahap penyelesaian (resolution stage) yang ditunjukkan pada gambar 1 (Lee dkk. 2003).

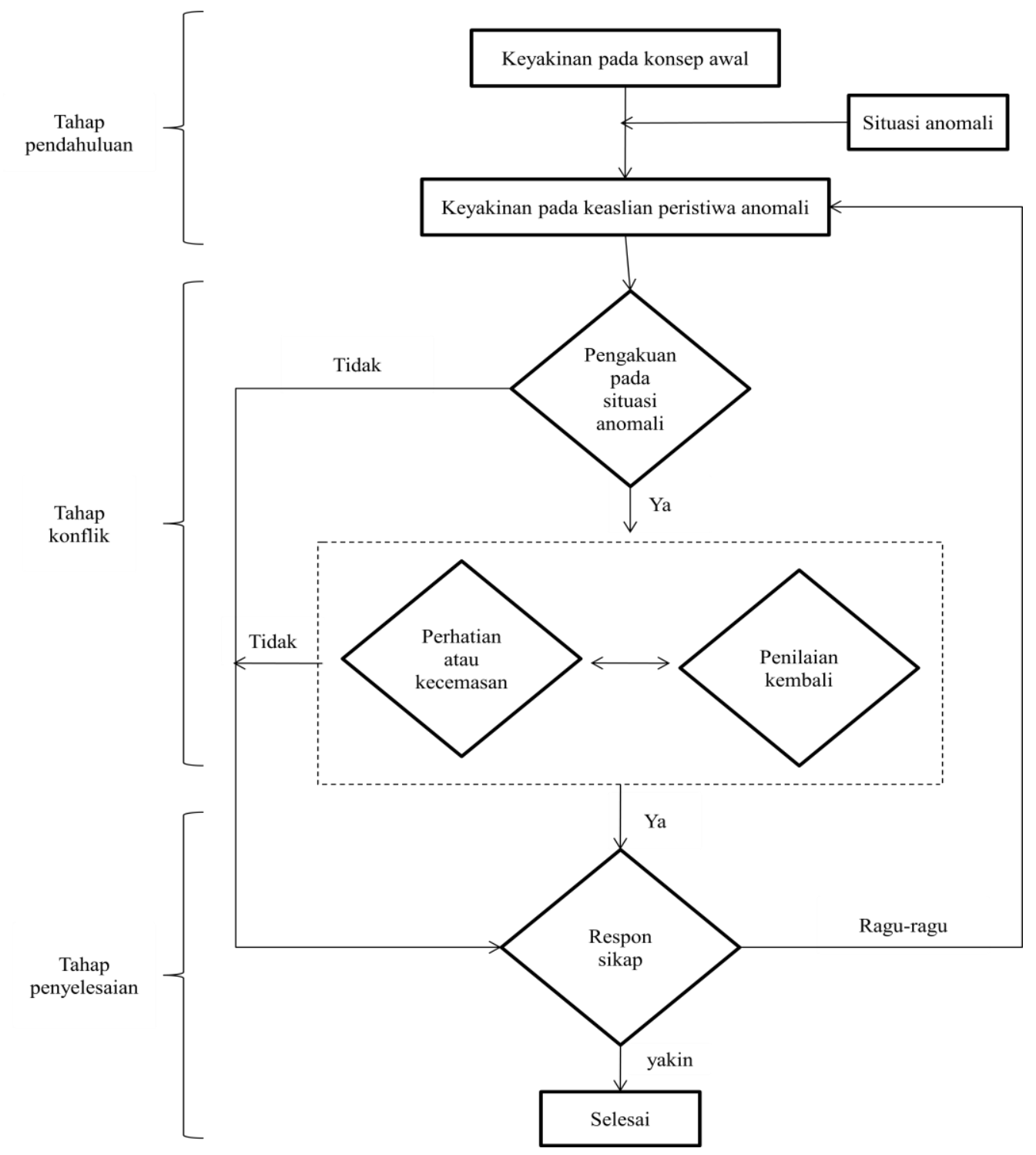

Gambar 1. Proses Konflik Kognitif 
Keterangan:

Tahap pendahuluan : dilakukan dengan penyajian konflik

Tahap konflik : : penciptaan konflik dengan bantuan kegiatan yang melibatkan proses asimilasi dan akomodasi

Tahap penyelesaian $\quad$ : kegiatan diskusi dan menyimpulkan hasil diskusi

Menurut Movhovitz (Hardiansyah 2015) terdapat beberapa pendekatan terkait strategi pembelajaran untuk memperbaiki konsepsi siswa yang mendasarkan pada konflik kognitif dan resolusinya, yakni (1) siswa mengalamai anomali, tertarik serta terkejut secara bersamaan ketika mengamati hasil demonstrasi, (2) terjadi kecemasan diawal kegiatan belajar yang menjadikan siswa berpikir, serta bekerja untuk memecahkan masalah, dan (3) siswa mampu menangani situasi konflik kognitif pada dirinya yang ditunjukkan dengan adanya pemecahan masalah. Adapun kelebihan dari strategi ini adalah ketika miskonsepsi dalam diri siswa tersebut dihadapkan secara langsung dengan pengalaman yang akan menimbulkan ketidakseimbangan dan diikuti akomodasi, maka rasa ketidakpuasan siswa terhadap pemahaman awal mereka meningkat dan tertantang untuk melakukan restrukturisasi konsep (Bertiec dan Nasrudin, 2013).

Berdasarkan uraian yang telah dijelaskan di atas, maka peneliti berkeinginan untuk melakukan penelitian dengan judul "Keefektifan Pembelajaran POGIL dengan Strategi Konflik Kognitif untuk Mengurangi Miskonsepsi pada Materi Laju Reaksi Kelas XI SMA", dengan tujuan untuk mengidentifikasi jenis miskonsepsi siswa SMA pada materi laju reaksi serta memperbaiki miskonsepsi yang terjadi menggunakan model pembelajaran POGIL dengan strategi konflik kognitif.

\section{METODE}

Penelitian ini dilakukan pada 32 siswa kelas XI salah satu SMA di Sidoarjo yang telah mendapat materi laju reaksi. Rancangan penelitian yang digunakan adalah one group pretest-postes menggunakan tes diagnostik untuk mengetahui keefektifan model pembelajaran POGIL dengan strategi konflik kognitif dalam memperbaiki miskonsepsi yang dialami oleh siswa. Dengan demikian, dapat diketahui lebih akurat keefektifan pembelajaran remidial yang diberikan karena dapat membandingkan hasil sebelum dan sesudah perlakuan (Sugiyono 2001).

Instrumen yang digunakan dalam penelitian ini adalah tes diagnotis two-tier dan wawancara yang berfungsi sebagai pengumpul data jenis miskonsepsi siswa. Hal ini dilakukan sesuai dengan pernyataan (Dhindsa, Treagust, dan Treagust, 2009) dan Fermintasari (2015) yang menyarankan bahwa dalam penggunaan tes pilihan ganda dua tingkat sebaiknya disertai dengan wawancara. Selain itu Ta, Yalçinkaya, dan Boz, (2010) juga mengemukakan bahwa tingkat pemahaman siswa dapat diketahui secara lebih detail melalaui wawancara. Dengan adanya wawancara dapat melaporkan kepercayaan diri siswa dalam tanggapan mereka pada jawaban yang telah dituliskan pada tes pilihan ganda dua tingkat.

Adapun pokok bahasan yang diujikan untuk mengetahui pemahaman konsep siswa diantaranya adalah konsep dasar laju reaksi, teori tumbukan, persamaan laju reaksi dan orde reaksinya, serta faktor-faktor yang memengaruhi laju reaksi. Setelah teridentifikasi jenis miskonsepsi yang dialami siswa, maka dilakukan pembelajaran remidial menggunakan model pembelajaran POGIL dengan strategi konflik kognitif untuk memperbaiki miskonsepsi. Keefektifan dari pembelajaran ini dapat diketahui dengan membandingkan persentase jumlah siswa yang mengalami miskonsepsi sebelum dan sesudah diberikan perlakuan untuk siswa yang mengalami perubahan konsep dari miskonsepsi menjadi paham konsep. Tingkat keefektifan pembelajaran remidial yang dilakukan dapat ditentukan berdasarkan pada tabel 1.

Tabel 1. Tingkat Keefektifan Pembelajaran Remidial

\begin{tabular}{ccc}
\hline No & Persentase & Kategori Keefektifan \\
\hline 1 & $0-20$ & Sangat rendah \\
2 & $21-40$ & Rendah \\
3 & $41-60$ & Sedang \\
4 & $61-80$ & Tinggi \\
5 & $81-100$ & Sangat tinggi \\
\hline
\end{tabular}

\section{HASIL}

Jenis Miskonsepsi Siswa

Hasil temuan miskonsepsi siswa didapat dari tes diagnostik yang dilakukan kepada 32 siswa yang disertai dengan wawancara untuk siswa yang diduga mengalami miskonsepsi sehingga siswa dapat dikategorikan berdasarkan tingkat pemahaman konsepnya. Berdasaran kategori pemahaman siswa maka siswa dapat dikelompokkan menjadi tiga kategori, yakni miskonsepsi, paham konsep, dan tidak paham konsep. Adapun hasil data yang didapatkan berdasarkan kategori pemahamannya ditunjukkan pada gambar 2 . 


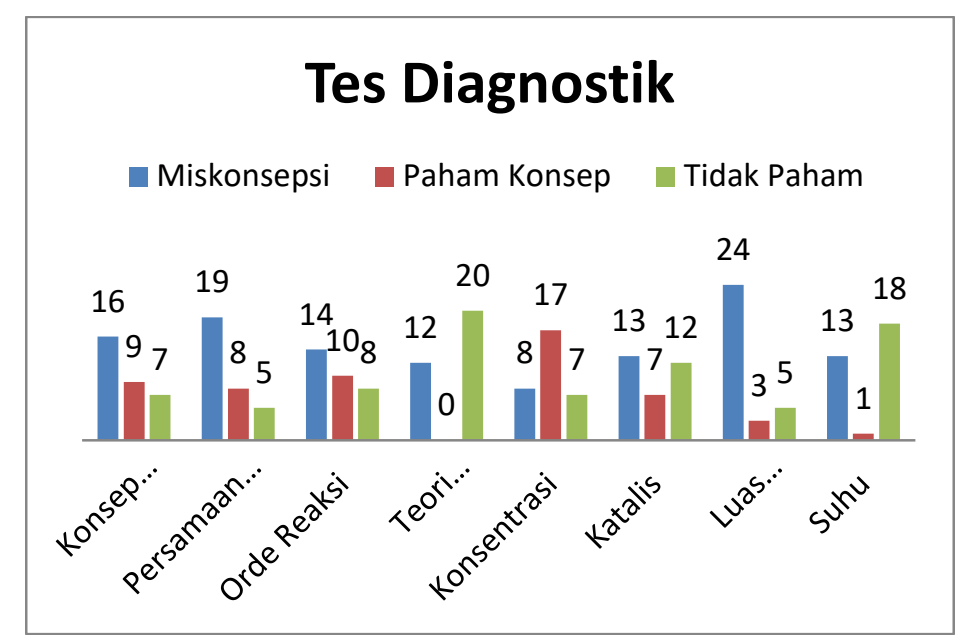

\section{Gambar 2. Grafik Tingkat Pemahaman Siswa Sebelum Perlakuan}

Berdasarkan grafik yang ditunjukkan pada gambar 2, diketahui bahwa untuk setiap pokok bahasan yang diujikan ditemukan miskonsepsi yang dialami oleh siswa. Dari delapan pokok bahasan yang diujikan, ditemukan terdapat tiga pokok bahasan yang menunjukkan terdapat lebih dari atau sama dengan 50\% siswa yang mengalami miskonsepsi, yakni pada pokok bahasan konsep dasar laju reaksi, persamaan laju reaksi, serta luas permukaan sebagai faktor laju reaksi. Adapun Jenis-jenis miskonsepsi yang ditemukan ditunjukkan pada tabel 2.

Tabel 2. Jenis Miskonsepsi yang Ditemukan

\begin{tabular}{cccl}
\hline No & Pokok Bahasan & & \multicolumn{1}{c}{ Jenis Miskonsepsi } \\
\hline 1. & Konsep dasar laju reaksi & - & Laju reaksi merupakan waktu yang diperlukan untuk memulai reaksi \\
& & - & Laju reaksi semakin cepat dengan bertambahnya waktu \\
\hline 2. & Persamaan laju reaksi & - & Semua reaktan menentukan persamaan laju reaksi \\
& & - & Persamaan laju reaksi $v=k$ tidak ada \\
& & - & Persamaan laju reaksi $v=k$ memiliki orde reaksi 1 \\
\hline 3. & Pengaruh luas permukaan & - & Semakin besar ukuran reaktan maka luas permukaannya semakin besar \\
& & & sehingga laju reaksi akan semakin lambat \\
\hline
\end{tabular}

\section{Keefektifan Pembelajaran Remidial}

Keefektifan pembelajaran remidial yang dilakukan dapat dilihat dari perbandingan jumlah siswa yang teridentifikasi miskonsepsi sebelum diberikan perlakuan dengan jumlah siswa yang mengalami perubahan konsep dari miskonsepsi menjadi paham konsep setelah diberikan perlakuan. Adapun hasil yang didapakan ditunjukkan pada tabel 3. Selain didapatkan data bahwa terjadi perubahan konsep untuk siswa yang mengalami miskonsepsi menjadi paham konsep, pembelajaran remidial yang dilakukan juga menunjukkan hasil lain sebagai efek samping dari pembelajaran yang dilakukan. Hasil efek samping yang didapatkan dari pembelajaran yang dilakukan ditunjukkan pada tabel 4 .

Tabel 3. Kefektifan Pembelajaran Remidial

\begin{tabular}{lcc}
\hline \multirow{2}{*}{ Pokok Bahasan } & Jumlah siswa yang mengalami perubahan konsep \\
\cline { 2 - 3 } & Miskonsepsi & Paham Konsep \\
\hline Konsep dasar laju reaksi & 16 & 8 \\
Persamaan laju reaksi & 19 & 13 \\
Faktor luas permukaan & 24 & 21 \\
\hline
\end{tabular}


Tabel 4. Efek Samping Pembelajaran Remidial

\begin{tabular}{|c|c|c|c|c|c|c|}
\hline \multirow[t]{2}{*}{ Pokok Bahasan } & \multicolumn{2}{|c|}{$\begin{array}{c}\text { Jumlah siswa yang mengalami } \\
\text { perubahan konsep }\end{array}$} & \multicolumn{2}{|c|}{$\begin{array}{c}\text { Jumlah siswa yang mengalami } \\
\text { perubahan konsep }\end{array}$} & \multicolumn{2}{|c|}{$\begin{array}{c}\text { Jumlah siswa yang mengalami } \\
\text { perubahan konsep }\end{array}$} \\
\hline & Tidak Paham & Paham Konsep & Miskonsepsi & Tidak Paham & Tidak Paham & Miskonsepsi \\
\hline $\begin{array}{l}\text { Konsep dasar laju } \\
\text { reaksi }\end{array}$ & 7 & 5 & 16 & 4 & 7 & 1 \\
\hline Persamaan laju reaksi & 5 & 5 & 19 & 2 & 5 & 0 \\
\hline $\begin{array}{l}\text { Faktor luas } \\
\text { permukaan }\end{array}$ & 5 & 4 & 24 & 0 & 5 & 0 \\
\hline
\end{tabular}

\section{PEMBAHASAN}

Studi identifikasi miskonsepsi yang dilakukan pada siswa kelas XI SMA yang telah menempuh materi laju reaksi dilakukan untuk mengetahui keefektifan pembelajaran POGIL dengan strategi konflik kognitif dalam mereduksi miskonsepsi yang dialami siswa. Data jenis miskonsepsi didapatkan melalui tes diagnostik disertai dengan wawancara. Selanjutnya, miskonsepsi yang ditemukan tersebut kemudian diperbaiki menggunakan pembelajran POGIL dengan strategi konflik kognitif. Selama proses pembelajaran berlangsung, siswa dikelompokkan menjadi beberapa kelompok sesuai dengan tingkat pemahaman konsepnya, yakni siswa yang mengalami miskonsepsi dikelompokkan dengan siswa yang mengalami miskonsepsi, begitu pula untuk siswa yang tidak paham konsep dan paham konsep. Hal ini dilakukan dengan maksud agar pembelajaran lebih efektif dan bisa lebih terfokuskan pada siswa-siswa yang mengalami miskonsepsi maupun tidak paham konsep dengan tidak mengenyampingkan siswa yang telah memahami konsep.

\section{Jenis Miskonsepsi Siswa \\ Konsep Dasar Laju Reaksi}

Siswa yang mengalami miskonsepsi pada pokok bahasan konsep dasar laju reaksi ditemukan sebanyak 50\%. Siswa yang mengalami miskonsepsi beranggapan bahwa "selama reaksi kimia berlangsung jumlah reaktan akan bertambah, sedangkan jumlah produk berkurang". Berdasarkan hasil wawancara yang dilakukan ternyata masih ditemukan siswa yang belum mampu memahami perbedaan reaktan dan produk sehingga dapat dimungkinkan penyebab siswa mengalami miskonsepsi tersebut adalah ketidak mampuan siswa dalam menentukan reaktan dan produk pada reaksi kimia.

Selain itu, juga ditemukan siswa menyatakan bahwa "laju reaksi akan semakin meningkat dengan bertambahnya waktu". Pernyataan ini sama dengan hasil temuan sebelumnya yang dilakukan oleh Cakmakci (2005). Pemahaman siswa terhadap laju reaksi tersebut berdampak pada kesalahan siswa dalam menentukan grafik laju reaksi. Kesalahan yang terjadi pada siswa dalam menggambarkan grafik laju reaksi dikarenakan terjadi kesalahan konsep pada diri siswa dalam memahami hubungan laju reaksi terhadap waktu reaksi.

Penemuan lain dari miskonsepsi yang dialami siswa adalah bahwa”laju reaksi merupakan waktu yang diperlukan reaktan untuk memulai reaksi". Berdasarkan hasil wawancara lebih lanjut yang dilakukan terhadap pernyataan tersebut, siswa beranggapan bahwa diperlukan waktu bagi reaktan untuk bereaksi sehingga terbentuk produk, yang artinya reaksi bisa saja baru terjadi beberapa detik setelah reaktan dicampurkan. Dengan kata lain, reaksi tidak langsung terjadi sejak awal reaktan dicampurkan.

\section{Persamaan Laju Reaksi}

Pada pokok bahasan persamaan laju reaksi ditemukan sebanyak 19 siswa (59\%) mengalami miskonsepsi. Siswa yang mengalami miskonsepsi tersebut menyatakan bahwa "semua reaktan adalah penentu persamaan laju reaksi". Berdasarkan pernyataan tersebut maka dapat diketahui bahwa siswa memahami yang menjadi penentu persamaan laju reaksi adalah konsentrasi dari reaktan. Namun ketika siswa dihadapkan dengan kondisi dimana ketika persamaan laju reaksinya adalah $v=k$ siswa menyatakan bahwa persamaan laju reaksi tersebut tidak ada. Hal ini dikarenakan persamaan laju tersebut tidak sesuai dengan pemahaman konsep siswa yang mana dalam penulisan persamaan laju reaksi akan selalu diikuti oleh konsentrasi dari reaktan.

Adapun hasil wawancara yang dilakukan untuk menggali informasi terhadap pemahaman konsep siswa pada pokok bahasan penentuan laju reaksi dapat ditunjukkan pada percakapan berikut:
$P$ : Bisakah kamu menentukan persamaan laju reaksi dari $2 X Y \rightarrow X_{2}+Y_{2}$ ?
S: Bisa
$P$ : Coba tuliskan jika kamu bisa menentukannya?
$S: v=k[X Y]^{2}$ 
Hasil ini menunjukkan bahwa siswa menentukan persamaan laju reaksi langsung dari persamaan reaksinya. Artinya, siswa beranggapan tanpa melalui percobaan, persamaan laju reaksi sudah dapat ditentukan. Berdasarkan jawaban yang diberikan oleh siswa dalam menentukan persamaan laju reaksi berdampak pada pemahaman siswa dalam menentukan orde reaksi dari masing-masing reaktan. Jika siswa menentukan persamaan laju berdasarkan persamaan reaksinya, maka penentuan orde reaksinya dapat ditentukan berdasarkan koefisien reaksinya, seperti yang ditunjukkan pada saat tes diagnostik serta wawancara.

\section{Luas permukaan sebagai faktor yang memengaruhi laju reaksi}

Salah satu faktor laju reaksi adalah luas permukaan. Hasil penelitain menujukkan bahwa terdapat 24 siswa (75\%) yang mengalami miskonsepsi. Miskonsepsi yang ditemukan menujukkan bahwa siswa menyatakan "semakin kecil luas permukaan maka laju reaksinya akan semakin cepat". Hal ini berkebalikan dengan hasil penelitian yang didapatkan oleh Amarlita (2010) yang menyatakan bahwa siswa yang mengalami miskonsepsi beranggapan semakin besar ukuran preaksi, maka laju reaksi akan semakin cepat.

Kesalahan konsep yang terjadi tersebut dikarenakan siswa memahami jika semakin besar ukuran reaktan maka luas permukaannya akan semakin besar untuk zat dengan massa yang sama. Kesalahan yang dialami siswa dalam membandingkan luas permukaan disebabkan siswa membandingkan zat yang masih dalam kondisi bongkahan besar dengan zat yang telah terbagi menjadi ukuran yang lebih kecil dalam jumlah yang sama yakni masing-masing adalah satu butir, bukan membandingkannya dalam massa yang sama.

\section{Keefektifan Pembelajaran Remidial}

Hasil penelitian menjukkan bahwa jumlah siswa yang mengalami miskonsepsi sebelum dan sesudah perlakuan terjadi penurunan. Pada pokok bahasan konsep dasar laju reaksi didapatkan persentase keefektifan pembelajaran yang dilakukan sebesar 50\%, pada pokok bahasan persamaan laju reaksi sebesar 68,42\%; serta pada pokok bahasan pengaruh luas permukaan terhadap laju reaksi sebesar $87,50 \%$ dari total jumlah siswa yang mengalami miskonsepsi. Berdasarkan hasil yang didapatkan tersebut maka dapat disimpulkan bahwa pembelajaran remidial yang dilakukan secara umum efektif dalam memperbaiki miskonsepsi dengan persentase keefektifan rata-rata sebesar $68,64 \%$. Keefektifan pembelajaran remidial yang dilakukan sejalan dengan hasil penelitian yang dilakukan oleh Amarlita (2010).

Selain efektif dalam memperbaiki miskonsepsi, pembelajaran remidial yang dilakukan juga terbukti efektif dalam memperbaiki konsep siswa yang tidak paham konsep. Adapun persentase keefektifan yang diperoleh untuk siswa yang mengalami perubahan konsep dari tidak paham konsep menjadi paham konsep untuk pokok bahasan konsep dasar laju reaksi sebesar 71,42\%; pokok bahasan persamaan laju reaksi sebesar $60 \%$, serta pada pokok bahasaan pengaruh luas permukaan terhadap laju reaksi $90,90 \%$ dari total jumlah siswa yang tidak paham konsep. Berdasarkan hasil yang didapatkan tersebut maka dapat disimpulkan bahwa pembelajaran remidial yang dilakukan secara umum efektif dalam memperbaiki konsep untuk siswa yang tidak paham konsep dengan persentase keefektifan rata-rata sebesar $74,11 \%$.

Hasil yang didapatkan tersebut menunjukkan bahwa pembelajaran yang dilakukan terbukti efektif dalam merubah konsep siswa, tidak hanya pada siswa yang mengalami miskonsepsi namun juga untuk siswa yang tidak paham konsep. Berdasarkan data tersebut maka didapatkan persentase rata-rata keefektifan pembelajaran remedial menggunakan model pembelajaran POGIL dengan strategi konflik kognitif sebesar 71,375\%. Selain itu, pembelajaran remidial yang telah dilakukan menunjukkan hasil perubahan konsep yang bervariasi. Tidak hanya mampu memperbaiki konsep dari miskonsepsi dan tidak paham konsep menjadi paham konsep, namun juga didapatkan data bahwa terdapat perubahan konsep yang lain yakni perubahan konsep dari miskonsepsi menjadi tidak paham konsep dan sebaliknya.

Hasil yang didapatkan untuk perubahan konsep dari miskonsepsi menjadi tidak paham konsep terjadi di pokok bahasan konsep dasar laju reaksi dan persamaan laju reaksi, sedangkan untuk perubahan konsep dari tidak paham konsep menjadi miskonsepsi terjadi pada pokok bahasan konsep dasar laju reaksi. Perubahan pemahaman konsep yang timbul sebagai efek samping dari pembelajaran remidial yang dilakukan dimungkinkan karena siswa kurang mampu dalam mengaitkan antar konsep serta konsep yang telah dipelajari tidak masuk dalam memori jangka panjang sehingga timbul lupa dalam diri siswa. Temuan efek samping ini perlu ditindaklanjuti untuk menemukan penyebab sesungguhnya dari efek samping yang didapatkan khususnya untuk efek samping yang terjadi perubahan konsep dari miskonsepsi menjadi tidak paham konsep dan sebaliknya.

\section{SIMPULAN}

Berdasarkan hasil penelitian yang dilakukan maka dapat disimpulkan bahwa pada materi laju reaksi miskonsepsi yang ditemukan untuk pokok bahasan konsep dasar laju reaksi, persamaan laju reaksi serta luas permukaan sebagai faktor laju reaksi adalah (a) Laju reaksi merupakan waktu yang diperlukan untuk memulai reaksi, (b) Laju reaksi semakin cepat dengan bertambahnya waktu, (c) Semua reaktan menentukan persamaan laju reaksi, (d) Persamaan laju reaksi $v=k$ tidak ada, (e) Persamaan laju reaksi $v=k$ memiliki orde reaksi 1 , (f) Semakin besar ukuran reaktan maka luas permukaannya semakin besar sehingga laju reaksi akan semakin lambat, sedangkan untuk keefektifan pembelajaran remidial menggunakan model pembelajaran POGIL dengan strategi konflik kognitif tergolong tinggi dalam memperbaiki miskonsepsi siswa. Saran yang dapat 
diberikan terkait dengan hasil penelitian yang dilakukan terhadap miskonsepsi adalah agar dalam pembelajaran materi laju reaksi kedepannya tidak terjadi miskonsepsi pada siswa, maka dalam membelajarkan materi laju reaksi perlu diperhatikan jenisjenis miskonsepsi yang telah ditemukan dalam penelitian ini.

\section{DAFTAR RUJUKAN}

Amarlita, D. M. (2010). Identifikasi Kesalahan Konep pada Materi Laju Reaksi Siswa Kelas XI SMA Negeri 1 Pagak dan Perbaikannya menggunakan Strategi Konflik Kognitif. Tesis tidak dipublikasikan. Universitas Negeri Malang, Malang.

Bertiec, N., Nasrudin, H. (2013). Penerapan Strategi Konflik Kognitif untuk Mereduksi Miskonsepsi Level Sub-Mikroskopik pada Materi Larutan Penyangga di SMA Negeri 1 Sumberejo Bojonegoro. Unesa Journal of Chemical Education, 2(3), $12-18$.

Cakmakci, G. (2005). A Cross-Sectional Study of the Understanding of Chemical Kinetics Among Turkish Secondary and Undergraduate Students. The University of Leeds School of Education., 294.

Cetin-Dindar, Ayla., Geban, O. (2011). Development of a Three-Tier Test to Assess High School Students' Understanding of Acids and Bases. Procedia - Social and Behavioral Sciences, 15, 600-604.

Coll, R. K., \& Treagust, D. F. (2001). Learners' Use of Analogy and Alternative Conceptions for Chemical Bonding. Australian Science Teachers Journal, 48(1), 24-32.

Dhindsa, H. S., David F Treagust., \& D Treagust. (2009). Conceptual Understanding of Bruneian Tertiary Students: Chemical Bonding and Structure, 1(1), 24-32.

Fermintasari, V. (2015). Keefektifan Tes Pilihan Ganda Dua tingkat dan Tes Pilihan Ganda Disertai Wawancara untuk Identifikasi Kesalahan Konsep Siswa dengan Kemampuan Berpikir Ilmiah Berbeda pada Materi Laju Reaksi Kelas XI IPA SMA Negeri 1 Lawang. Tesis tidak diterbitkan. Universitas Negeri Malang, Malang.

Fitriani, W., Irwandi, D., \& Murniati, D. (2017). Perbandingan Model Pembelajaran Process Oriented Guided Inquiry Learning (POGIL) dan Guided Inquiry (GI) terhadap Keterampilan Berpikir Kritis Siswa. JRPK: Jurnal Riset Pendidikan Kimia 7(1), 76-84.

Hanson, D. M. (2006). Instructor's Guide to Process-Oriented Guided-Inquiry Learning. Lisle, IL: Pacific Crest.

Hardiansyah. (2015). Pengembangan Perangkat Pembelajaran Stategi Konflik Kognitif Berbasis Eksperimen untuk Mereduksi Miskonsepsi IPA. Jurnal Ilmu Pendidikan LPMP Kalimantan Timur, 9(1).

Johnstone, A. H. (2000). Teaching of Chemistry - Logical or Psychological?. Chemistry Education Research Practice, 1(1), 915.

Kaya, E., \& Geban, Ö. (2012). Facilitating Conceptual Change in Rate of Reaction Concepts Using Conceptual Change Oriented Instruction. Education and Science, 37(163), 216-225.

Kolomuç, A., \& Tekin, S. (2011). Chemistry Teachers' Misconceptions Concerning Concept of Chemical Reaction Rate. Eurasian Journal of Physics Chemistry Education, 3(2), 84-101.

Lee, G., Kwon, J., Sang-Suk Park, Jung-Whan Kim, Hyeok-Gu Kwon., \& Hac-Kyoo Park. (2003). Development of an Instrument for Measuring Cognitive Conflict in Secondary-Level Science Classes. Journal of Research in Science Teaching, 40(6), 585-603.

Nakhleh, M. B. (1992). Why Some Students Don't Learn Chemistry: Chemical Misconceptions. Journal of Chemical Education 69(3), 191.

Nicoll, G. (2001). A Report of Undergraduates’ Bonding Misconceptions. International Journal of Science Education, 23(7), 707-730.

Posner, G. J., Kenneth A. Strike, Peter W. Hewson., \& William A. Gertzog. (1982). Accommodation of a Scientific Conception: Toward a Theory of Conceptual Change. Science Education, 66(2), 211-217.

Sadeh, I., \& Zion, M. (2009). The Development of Dynamic Inquiry Performances within an Open Inquiry Setting: A Comparison to Guided Inquiry Setting. Journal of Research in Science Teaching, 46(10), 1137-1160.

Santoso, T., \& Supriadi. (2015). Pembelajaran Penalaran Argument Berbasis Peta Konsep untuk Remidiasi Miskonsepsi Laju Reaksi Kimia. Jurnal Ilmu Pendidikan, 21(1), 80-87.

Sirhan, G. (2007). Learning Difficulties in Chemistry: An Overview. Journal of Turkish Science Education, 4(2), 2-22.

Sugiyono. (2001). Metode Penelitian. Bandung: Alfabeta.

Ta, Ö., Yalçinkaya, E., \& Yezdan Boz. (2010). Pre-Service Chemistry Teachers' Ideas about Reaction Mechanism. Journal of Turkish Scinece Education, 7(1), 47-60.

Treagust, D. F. (1988). Development and Use of Diagnostic Tests to Evaluate Students' Misconceptions in Science. International Journal of Science Education, 10(2), 159-169. https://doi.org/10.1080/0950069880100204.

Wandersee, J. H. (1986). Can the History of Science Help Science Educators Anticipate Students' Misconceptions? Journal of Research in Science Teaching, 23(7), 581-597. https://doi.org/10.1002/tea.3660230703. 